\begin{tabular}{|l|l||r|}
\hline \multirow{2}{*}{\begin{tabular}{|l|l|} 
Al Fitrah \\
Journal Of Early Childhood Islamic Education
\end{tabular}} & Sumber Belajar dan Alat Permainan \\
ISSN : 2599-2287 E-ISSN : 2622-335X & Untuk PAUD \\
Vol.2 No.1 Juli 2018 & Nurlaili \\
\hline
\end{tabular}

\title{
SUMBER BELAJAR DAN ALAT PERMAINAN \\ UNTUK PENDIDIKAN ANAK USIA DINI
}

\begin{abstract}
Abstrak
Belajar merupakan komponen ilmu pendidikan yang berhubungan dengan tujuan dan bahan acuan interaksi, baik yang bersifat eksplisit maupun implisit (tersembunyi). Belajar dan pembelajaran dimulai dari peserta didik dari anak usia dini sampai dengan dewasa. Oleh karena itu, belajar merupakan salah satu faktor yang mempengaruhi dan berperan penting dalam pembentukan pribadi dan perilaku individu, karena sebagian terbesar perkembangan individu berlangsung melalui kegiatan belajar. Agar proses belajar dan pembelajaran anak usia dini berjalan dengan efektif dan efesien, maka diperlukan berbagai sumber belajar, alat permainan yang menarik agar proses pembelajaran disenangi oleh anak. Pendidikan anak usia dini adalah usaha yang dilakukan oleh orang dewasa kepada anak usia 0-8 tahun dengan tujuan untuk mengembangkan potensi yang ada dalam diri anak sesuai dengan pertumbuhan dan perkembangan fisik dan rohaninya. Dalam pengembangan potensi yang ada pada anak usia dini, orang tua atau pendidik harus menggunakan sumber belajar dan alat permainan edukatif yang sesuai dengan pertumbuhan dan perkembangan anak.
\end{abstract}

\section{Pendahuluan}

Belajar pada hakekatnya adalah proses interaksi terhadap semua situasi yang ada disekitar individu siswa. Belajar dapat dipandang sebagai proses yang diarahkan kepada pencapaian tujuan dan proses berbuat melalui berbagai pengalaman yang diciptakan guru. Kualitas kegiatan pembelajaran yang dilakukan sangat bergantung pada perencanaan, pelaksanaan proses pembelajaran dan evaluasi pembelajaran yang dilakukan guru.

Belajar merupakan komponen ilmu pendidikan yang berhubungan dengan tujuan dan bahan acuan interaksi, baik yang bersifat eksplisit maupun implisit (tersembunyi). Belajar bisa dikatakan sebagai proses interaksi antara berbagai unsur yang saling berkaitan. Dimana unsurunsur dalam belajar adalah individu sebagai peserta belajar, kebutuhan sebagai sumber pendorong, situasi belajar yang memberikan kemungkinan terjadinya kegiatan belajar, sumber belajar dan lainlain.

Dengan demikian maka perwujudan belajar atau perbuatan belajar dinyatakan dalam bentuk perubahan tingkah laku 


\begin{tabular}{|l|l||r|}
\hline & Al Fitrah & Sumber Belajar dan Alat Permainan \\
Journal Of Early Childhood Islamic Education & Untuk PAUD \\
ISSN : 2599-2287 E-ISSN : 2622-335X & Nurlaili \\
\hline & & \\
\hline
\end{tabular}

dalam proses belajar. Untuk itu, akan dapat meningkatkan kesehatan dan implimentasi belajar adalah kegiatan individu memperoleh pengetahuan, perilaku, dan keterampilan dengan cara mengolah bahan belajar melalui sumber belajar yang baik. Menurut Endang Kumara $^{1}$, inti dari belajar dilihat dari pandangan psikologi adalah adanya perubahan kematangan bagi anak didik sebagai akibat belajar, sedangkan dilihat dari proses adalah adanya interaksi antara peserta didik dengan pendidik sebagai proses pembelajaran. Sejalan dengan pedapat Syamsudin Makmun ${ }^{2}$, bahwa perubahan dalam konteks belajar itu dapat bersifat fungsional atau struktural, material, dan behavioral serta keseluruhan pribadi.

Belajar dan pembelajaran dimulai dari peserta didik dari anak usia dini sampai dengan dewasa. Namun dalam proses pelaksanaan belajar dan pembelajarannya terdapat perbedaan dalam pencapaian tujuannya. Pendidikan anak usia dini merupakan wilayah pembahasan yang sangat luas dan menarik. Karena usia dini merupakan awal bagi pertumbuhan dan perkembangan anak untuk belajar ke jenjang selanjutnya. Anak yang mendapatkan pembinaan sejak usia dini

Endang Komara, Belajar dan Pembelajaran Interaktif, Bandung : Refika Aditama, 2014, hlm. 13

2 Syamsudin Makmun. 2007. Psikologi Kependidikan: Perangkat Sistem Pengajaran Modul, Bandung : Rosdakarya, hlm. 159 kesejahteraan fisik dan mental, yang itu akan berdampak pada peningkatan prestasi belajar, eos kerja dan produktivitas. Pada akhirnya anak akan lebih mampu untuk mandiri dan mengoptimalkan potensi yang dimiliki.

Oleh karena itu, belajar merupakan salah satu faktor yang mempengaruhi dan berperan penting dalam pembentukan pribadi dan perilaku individu, karena sebagian terbesar perkembangan individu berlangsung melalui kegiatan belajar. Agar proses belajar dan pembelajaran anak usia dini berjalan dengan efektif dan efesien, maka diperlukan berbagai sumber belajar, alat permainan yang menarik agar proses pembelajaran disenangi oleh anak.

B. Pembahasan

\section{Pendidikan Anak Usia Dini}

Pendidikan anak usia dini merupakan wilayah pembahasan yang sangat luas dan menarik. Karena usia dini merupakan awal bagi pertumbuhan dan perkembangan anak. Hal itu akan membawa dampak bagi sepanjang kehidupan anak selanjutnya. Penelitian dan pengkajian terhadap pendidikan anak juga kian meningkat. Diharapkan dengan perhatian dan kesadaran terhadap pendidikan anak usia dini yang semakin 


\begin{tabular}{|l|l|r|}
\hline A1 Fitrah & Sumber Belajar dan Alat Permainan \\
\hline Journal Of Early Childhood Islamic Education & Untuk PAUD \\
ISSN : 2599-2287 E-ISSN : 2622-335X & Nurlaili \\
\hline
\end{tabular}

baik akan membawa dampak positif bagi perkembangan anak selanjutnya.

\section{a. Pengertian Anak Usia Dini}

Menurut Undang-Undang Republik Indonesia Nomor 20 tahun 2003 tentang sistem pendidikan nasional, menyatakan bahwa pendidikan anak usia dini adalah suatu upaya pembinaan yang ditujukan kepada anak sejak lahir sampai dengan usia enam tahun yang dilakukan melalui pemberian rangsangan pendidikan untuk membantu pertumbuhan dan perkembangan jasmani dan rohani, agar anak memiliki kesiapan dalam memasuki pendidikan lebih lanjut ${ }^{3}$. Penjelasan tentang pertumbuhan dan perkembangan fisik seperti koordinasi motorik halus dan kasar, sedangkan pertumbuhan dan perkembangan rohani seperti sikap, perilaku dan agamanya.

Anak usia dini merupakan usia emas (the golden age) yang sangat potensial untuk melatih dan mengembangkan berbagai potensi multi kecerdasan yang dimiliki anak ${ }^{4}$. Begitu juga pendapat Hibana S. Rahman ${ }^{5}$ mengatakan pendidikan anak usia dini adalah upaya yang terencana dan sistematis yang

\footnotetext{
${ }^{3}$ Undang-Undang RI Nomor 20 Tahun 2003 tentang Sistem Pendidikan Nasional

4 Harun Rasyid, dkk, Asesmen Perkembangan Anak Usia Dini, Yogyakarta : Multi Pressindo, 2009, hlm. 64

5 Hibana S. Rahman, Konsep Dasar Pendidikan Anak Usia Dini, Yogyakarta : PGTKI Press, 2005, hlm. 2
}

dilakukan oleh pendidik atau pengasuh anak usia 0-8 tahun dengan tujuan agar anak mampu mengembangkan potensi yang dimiliki secara optimal.

Dari beberapa pendapat diatas, dapat disimpulkan bahwa pendidikan anak usia dini adalah usaha yang dilakukan oleh orang dewasa kepada anak usia 0-8 tahun dengan tujuan untuk mengembangkan potensi yang ada dalam diri anak sesuai dengan pertumbuhan dan perkembangan fisik dan rohaninya.

b. Tujuan dan Fungsi Pendidikan Anak Usia Dini

Pendidikan anak usia dini telah banyak diselenggarakan oleh masyarakat, karena kesadaran masyarakat akan pentingnya pendidikan untuk anak usia dini semakin baik. Berbagai macam bentuk lembaga pendidikan anak mulai bermunculan dengan segala kekhasannya.

Pendidikan anak usia dini bertujuan untuk mengembangkan seluruh potensi anak agar nantinya dapat berfungsi sebagai manusia yang utuh sesuai dengan falsafah suatu bangsa ${ }^{6}$.

Secara umum tujuan program pendidikan anak usia dini adalah memfasilitasi pertumbuhan dan perkembangan anak secara optimal dan

6 Slamet Suyanto, Konsep Dasar Pendidikan Anak Usia Dini, Jakarta : Depdiknas, 2005, hlm. 5 


\begin{tabular}{|l|l|r|}
\hline \begin{tabular}{|l|l|}
\hline \\
$y$
\end{tabular} & Al Fitrah & Sumber Belajar dan Alat Permainan \\
Journal Of Early Childhood Islamic Education & Untuk PAUD \\
ISSN : 2599-2287 E-ISSN : 2622-335X & Nurlaili \\
& Vol.2 No.1 Juli 2018 & \\
\hline
\end{tabular}

menyeluruh sesuai dengan norma-norma dan nilai kehidupan yang dianut. Melalui program pendidikan yang dirancang dengan baik, anak akan mampu mengembangkan segenap potensi yang dimiliki, dari aspek fisik, sosial, moral, emosi, kepribadian dan lain-lain ${ }^{7}$.

Adapun secara khusus tujuan program pendidikan anak usia dini diantaranya adalah agar :

1. Anak mampu mengelola gerakan dan keterampilan tubuh, termasuk gerakan-gerakan yang mengontrol gerakan tubuh, gerakan halus dan gerakan kasar.

2. Anak memperoleh pengetahuan tentang pemeliharaan tubuh, kesehatan dan kebugaran tubuh.

3. Anak mampu berfikir secara kritis, memberi alasan, memecahkan masalah dan menemukan hubungan sebab akibat.

4. Anak mampu memanfaatkan indera penglihatan dan dapat menvisualisasikan suatu obyek, termasuk mampu menciptakan imajinasi mental internal dan gambar-gambar.

5. Anak mampu mengembangkan konsep diri dan sikap positif

7 Hibana S. Rahman, Konsep Dasar Pendidikan Anak Usia Dini, Yogyakarta : PGTKI Press, 2005, hlm. 6 terhadap belajar, control diri dan rasa memiliki.

6. Anak mampu mengenal, memahami serta mengapresiasi flora dan fauna dan lingkungan alam sebagai kebesaran ciptaan Allah.

7. Anak mampu menggunakan bahasa untuk dapat berkomunikasi secara efektif yang bermanfaat untuk belajar dan berfikir ${ }^{8}$.

Dapat disimpulkan bahwa tujuan dari program pendidikan anak usia dini adalah mengembangkan seluruh potensi atau kemampuan yang dimiliki anak sesuai dengan tahap pertumbuhan dan perkembangan anak dengan cara memberikan stimulus yang tepat. Namun pemberian stimulus bagi anak usia dini berbeda dengan orang dewasa. Hal ini dikarenakan anak usia dini bukan miniatur orang dewasa, anak usia dini memiliki karakteristik tersendiri.

c. Pentingnya Pendidikan Anak Usia Dini

Pendidikan anak usia dini memegang peranan yang sangat penting dalam menentukan perkembangan anak selanjutnya, karena pendidikan anak usia dini merupakan pondasi awal kepribadian anak. Anak yang mendapatkan pembinaan sejak usia dini akan dapat meningkatkan kesehatan, kesejahteraan fisik dan mental,

\footnotetext{
${ }^{8}$ Ibid hal 7-8
} 


\begin{tabular}{|l|l|r|}
\hline A1 Fitrah & Sumber Belajar dan Alat Permainan \\
\hline Journal Of Early Childhood Islamic Education & Untuk PAUD \\
ISSN : 2599-2287 E-ISSN : 2622-335X & Nurlaili \\
\hline
\end{tabular}

dan itu akan berdampak pada peningkatan prestasi belajar, etos kerja dan produktivitas, sehingga akhirnya anak akan lebih mampu untuk mandiri dan mengoptimalkan potensi yang dimilikinya.

Pendidikan anak usia dini dapat juga dikatakan sebagai cermin untuk melihat bagaimana keberhasilan anak dimasa yang akan datang. Karena anak yang mendapatkan layanan yang baik semenjak usia 0 tahun hingga 8 tahun memiliki harapan yang lebih besar untuk meraih keberhasilan di masa mendatang. Sebaliknya anak yang tidak menerima pelayanan pendidikan yang memadai pada usia dini, maka dia akan melakukan perjuangan yang berat dalam mengembangkan kehidupan selanjutnya.

d. Prinsip-Prinsip Pendidikan Anak Usia Dini

Pendidikan anak usia dini memiliki prinsip khusus, sebagaimana dirumuskan oleh Tina Bruce (1987), seperti yang ditulis oleh Aswarni Sudjud (1997) dan dikutif oleh Hibana S. Rahman', diantaranya adalah :

1. Pembelajaran pada usia dini saling terkait, tidak dapat dipisahkan

2. Fisik, mental dan kesehatan sama pentingnya seperti berfikir dan aspek psikis lainnya. Keseluruhan

${ }^{9}$ Ibid, hlm, 51-52 aspek anak merupakan pertimbangan penting.

3. Program pendidikan anak usia dini perlu menekankan disiplin.

4. Orang yang ada disekitar anak dalam melaksanakan interaksi dengan anak merupakan hal penting.

5. Pendidikan anak usia dini merupakan interaksi antara anak dengan lingkungan, dimana dalam lingkungan tersebut termasuk orang dewasa dan pengetahuan itu sendiri.

2. Sumber Belajar

Sumber belajar pada hakekatnya bertujuan untuk mengembangkan berbagai potensi yang sesuai dengan karakteristik anak. Untuk itu sangat beragam dan bervariasi baik dalam hal kemampuan, sikap serta minatnya. Oleh sebab itu sumber belajar bagi anak usia dini sangat menentukan keberhasilan anak. Dengan sumber belajar anak dapat menjelajahi sumber pengalaman belajarnya, sehingga anak termotivasi dan mendapatkan kemudahan dalam kegiatan belajarnya. Belajr bagi anak usia dini tidak di rasakan sebagai beban tetapi menjadi bermain yang menyenangkan dan tidak membosankan. Sumber belajar dapat menjadikan pembelajaran berlangsung secara optimal dan efektif, apabila sang guru kreatif 


\begin{tabular}{|l|l|r|}
\hline Al Fitrah & Sumber Belajar dan Alat Permainan \\
Journal Of Early Childhood Islamic Education & Untuk PAUD \\
ISSN : 2599-2287 E-ISSN : 2622-335X & Nurlaili \\
\hline & Vol.2 No.1 Juli 2018 & \\
\hline
\end{tabular}

merancang pemanfaatan dari berbagai sumber belajar tersebut.

a. Pengertian Sumber Belajar

Sumber belajar adalah sumber pengetahuan yang memiliki beberapa macam pengertian, yaitu sumber belajar di tinjau dalam pengertian yang sempit sampai pada pengertian yang luas. Sumber belajar dalam cakupan yang sempit maka sumber belajar hanya tercakup pada buku-buku atau bahan-bahan tercetak lainnya seperti majalah, buletin dan sebagainya. Dan dapat diartikan sebagai semua sarana pengajaran yang dapat menyajikan pesan yang dapat di dengar (secara auditif) maupun yang dapat di lihat (secara visual) saja. Misalnya radio, televisi dan perangkat keras (hardware) ${ }^{10}$.

Menurut Sri Winarni ${ }^{11}$ pengertian sumber belajar bisa diartikan secara sempit dan secara luas, pengertian secara sempit diarahkan pada bahan-bahan cetak, sedangkan secara luas tidak lain adalah daya yang bisa dimanfaatkan guna kepentingan proses belajar mengajar, baik secara langsung maupun tidak langsung. Lebih lanjut, Sri Winarni mengatakan lingkungan yang ada disekitar anak-anak

10

http://sumberbelajaraudtrisnaatika.blogspot.co.id/ diunduh pada tanggal 7 November 2017

${ }^{11}$ Sri Winarni, Lingkungan sebagai Sumber Belajar, 2012, diunduh di

http://diarywiens.blogspot.co.id/2012/09/lingkungan -sebagai-sumber-belajar_11.html, pada tanggal 10 November 2017 merupakan salah satu sumber belajar yang dapat dioptimalkan untuk pencapaian proses hasil pendidikan yang berkualitas.

Dapat disimpulkan bahwa sumber belajar adalah manusia, bahan, kejadian, peristiwa, setting, teknis yang membangun kondisi yang memberikan kemudahan bagi anak didik untuk belajar memperoleh pengetahuan keterampilan dan sikap.

b. Fungsi Sumber Belajar

Sumber belajar memiliki fungsi sebagai berikut $^{12}$ :

1. Meningkatkan

produktivitas

pembelajaran dengan jalan:

mempercepat laju belajar dan membantu guru untuk menggunakan waktu secara lebih baik dan (b) mengurangi beban guru dalam menyajikan informasi, sehingga dapat lebih banyak membina dan mengembangkan gairah.

2. Memberikan kemungkinan pembelajaran yang sifatnya lebih individual, dengan cara:

(a) mengurangi kontrol guru yang kaku dan tradisional; dan (b) memberikan kesempatan bagi siswa untuk berkembang sesuai dengan kemampuannnya.

3. Memberikan dasar yang lebih ilmiah terhadap pembelajaran dengan cara: (a) perancangan program pembelajaran yang

$$
12
$$

http://ariedanarmy.blogspot.co.id/2012/01/fungsima nfaat-sumber-belajar.html, diunduh pada tanggal 10 November 2017 


\begin{tabular}{|c|c|c|}
\hline$\Leftrightarrow \Rightarrow$ & $\begin{array}{l}\text { A1 Fitrah } \\
\text { Journal Of Early Childhood Islamic Education } \\
\text { ISSN : 2599-2287 E-ISSN : 2622-335X } \\
\text { Vol.2 No.1 Juli } 2018\end{array}$ & $\begin{array}{r}\text { Sumber Belajar dan Alat Permainan } \\
\text { Untuk PAUD } \\
\text { Nurlaili }\end{array}$ \\
\hline
\end{tabular}

lebih sistematis; dan (b) pengembangan bahan pengajaran yang dilandasi oleh penelitian.

4. Lebih memantapkan pembelajaran, dengan jalan: (a) meningkatkan kemampuan sumber belajar; (b) penyajian informasi dan bahan secara lebih kongkrit.

5. Memungkinkan belajar secara seketika, yaitu: (a) mengurangi kesenjangan antara pembelajaran yang bersifat verbal dan abstrak dengan realitas yang sifatnya kongkrit; (b) memberikan pengetahuan yang sifatnya langsung.

6. Memungkinkan penyajian pembelajaran yang lebih luas, dengan menyajikan informasi yang mampu menembus batas geografis.

Selanjutnya menurut Fitria Novita Sari $^{13}$, fungsi sumber belajar dalam pembelajaran ialah memberikan kesempatan untuk mendapat pengetahuan dan memperkaya anak dengan menggunakan berbagai alat, buku, narasumber, tempat dan semua hal yang menambah pengetahuan anak. Fungsi sumber belajar yang lain adalah meningkatkan perkembangan anak dalam berbahasa. Caranya adalah dengan berbicara dan berkomunikasi dengan

http://fitrianovitasari6.blogspot.co.id/2014/12/penger tian-fungsi-jenis-jenis-dan.html, diunduh pada tanggal 10 November 2017 narasumber yang dapat mengembangkan pandangan anak dalam berbagai aspek kehidupan. Dengan demikian anak tidak hanya mendapat informasi dari guru melainkan juga dari para pembicara lain yang dihadirkan dikelas.

Dapat disimpulkan bahwa fungsi sumber belajar adalah membantu pendidik dan peserta didik dalam pelaksanaan proses belajar mengajar, sehingga peserta didik dapat lebih mudah memahami materi yang disampaikan oleh pendidik.

c. Sumber Belajar Anak Usia Dini

Ketersediaan sumber belajar merupakan potensi yang dapat dimanfaatkan secara optimal oleh guru. Namun guru harus kreatif mengenal berbagai sumber belajar sehingga dapat bermanfaat dalam menunjang proses pembelajaran anak. Secara umum dilihat dari segi pengembangannya, sumber belajar itu dapat di bedakan menjadi 2 macam/sumber/ jenis ${ }^{14}$ :

1. Sumber belajar yang di rencanakan/dirancang (by design) yaitu adalah segala sumber belajar yang secara sengaja dirancang atau di design untuk kepentingan pencapaian tujuan pembelajaran tertentu atau semua sumber belajar http://vhian.blogspot.co.id/2012/07/sumber-belajar-danmedia-pembelajaran.html, diunduh pada tanggal 11 November 2017 


\begin{tabular}{|l|l||r|}
\hline \begin{tabular}{|l|l|}
\hline \\
$y$
\end{tabular} & Al Fitrah \\
Journal Of Early Childhood Islamic Education & Sumber Belajar dan Alat Permainan \\
ISSN : 2599-2287 E-ISSN : 2622-335X & Untuk PAUD \\
Vol.2 No.1 Juli 2018 & Nurlaili \\
\hline
\end{tabular}

yang secara khusus telah di kembangkan untuk memberikan fasilitas belajar yang terarah dan bersifat formal.

2. Sumber belajar yang di manfaatkan atau di gunakan (by utilization) adalah sumber belajar yang tidak dirancang untuk kepentingan tujuan suatu kegiatan pembelajaran atau sumber belajar yang tidak secara khusus di didesain untuk keperluan pendidikan, namun dapat ditemukan, diaplikasikan dan digunakan untuk keperluan belajar. Contoh pasar, toko, museum, tokoh masyarakat dan sebagainya yang ada di lingkungan kita

Anak belajar dari berbagai sumber yang sesuai dengan kebutuhan dan tahapan perkembangannya. Segala sumber belajar dapat memberikan anak berbagai pengetahuan dan pengalaman yang membentuk perkembangan anak lebih maksimal. AECT (Association for Education Communication an Technology) 15, yaitu sebuah organisasi asosiasi komunikasi dan teknologi pendidikan mengklasifikasikan sumber belajar dalam enam jenis yaitu :

15 https://paudanakbermainbelajar.blogspot.co.id/2014/04/sumbersumber-belajar-untuk-anak-paud.html, diunduh pada tanggal 11 November 2017
1. Pesan (message)

Segala bentuk informasi yang harus dikirim oleh komponen lain kepada anak yang berbentuk ide, fakta, pengertian dan data.

2. Orang (people)

Orang yang memiliki keahlian dapat menjadi sumber belajar dengan memberikan informasi kepada anak, selain guru juga ada narasumber lain yang dapat didatangkan untuk anak dalam memberikan informasi, pengetahuan dan keterampilan secara langsung pada anak.

3. Bahan (material)

Bahan-bahan yang paling dekat dengan anak yang biasanya digunakan dalam praktik ditempat belajar. Seperti bahan-bahan berwarna, berbentuk, dengan tekstur tertentu memberikan informasi dan ilmu pengetahuan pada anak sehingga menjadi sumber belajar yang nyata.

4. Peralatan (tool)

Peralatan yang berupa media belajar/hardware yang dapat dilihat dan digunakan anak secara langsung, seperti media televisi, radio,video digital dan lain sebagainya dapat dijadikan sumber belajar untuk anak. 


\begin{tabular}{|l|l|r|}
\hline Al Fitrah & Sumber Belajar dan Alat Permainan \\
\hline Untuk PAUD \\
Journal Of Early Childhood Islamic Education & Nurlaili \\
\hline ISSN : 2599-2287 E-ISSN : 2622-335X & \\
Vol.2 No.1 Juli 2018 & \\
\hline
\end{tabular}

5. Teknik

Teknik berupa prosedur yang disiapkan dalam menggunakan bahan pelajaran, peralatan, situasi, dan orang yang menyampaikan pesan. Contohnya orang tua yang mengajarkan bagaimana memasang sepatu kemudian anak menirukannya dengan baik, maka terjadi teknik penyampaian belajar bagi anak.

6. Lingkungan (setting)

Eksplorasi lingkungan bagi anak mempunyai peranan yang sangat penting, karena anak secara langsung dapat belajar dari lingkungannya. Potensi lingkungan sebagai sumber belajar sangat besar, karena itu anak dapat diajak memahami seluas-luasnya nilai-nilai dan pengetahuan yang terdapat dari lingkungannya.

Dari berbagai pendapat diatas, dapat dikatakan bahwa sumber belajar bagi anak usia dini bisa diambil dari berbagai macam sumber, karena semua sumber belajar yang ada bisa mengoptimalisasikan proses belajar mengajar, sehingga pembelajaran dapat menjadi efektif dan efesien. Untuk itu, penggunaan sumber belajar yang tepat dalam kegiatan belajar mengajar, akan menjadikan anak didik menikmati proses belajar mengajar.

3. Alat Permainan Edukatif

a. Pengertian Alat Permainan

Pengertian alat permainan adalah semua alat yang digunakan anak untuk memenuhi naluri bermainnya, sedangkan alat permainan edukatif menurut Suryadi ${ }^{16}$ bahwa alat permainan edukatif adalah alat yang dirancang khusus sebagai alat untuk bantu belajar dan dapat mengoptimalkan perkembangan anak, disesuaikan dengan usia dan tingkat perkembangannya. Alat permainan edukatif merupakan media dari sistem yang pada dasarnya adalah proses yang sistematis dan sinergi dengan berbagai komponen seperti bahan kegiatan, prosedur didaktid,pengelompokan anak. Menurut Mayke Sugianto. T dalam Badru Zaman, $\mathrm{dkk}^{17}$, alat permainan edukatif adalah permainan yang sengaja dirancang secara khusus untuk kepentingan pendidikan.

Sedangkan Adams

$(1975)^{18}$

berpendapat bahwa permainan edukatif adalah semua bentuk permainan yang

16 Suryadi, Cara Efektif Memahami Perilaku Anak Usia Dini. Jakarta: EDSA Mahkota Tedjasaputra, 2007

${ }^{17}$ Badru Zaman, dkk, Media dan Sumber Belajar TK. Jakarta: Universitas Terbuka, 2007, hlm. 63

http://www.asikbelajar.com/2015/08/beberapapengertian-alat-permainan.html, diunduh pada tanggal 11 November 2017. 


\begin{tabular}{|l|l|r|}
\hline \begin{tabular}{|l|l|}
\hline \\
$y$
\end{tabular} & Al Fitrah & Sumber Belajar dan Alat Permainan \\
Journal Of Early Childhood Islamic Education & Untuk PAUD \\
ISSN : 2599-2287 E-ISSN : 2622-335X & Nurlaili \\
& Vol.2 No.1 Juli 2018 & \\
\hline
\end{tabular}

dirancang untuk memberikan pengalaman pendidikan atau pengalaman belajar kepada para pemainnya, termasuk permainan tradisional dan modern yang diberi muatan pendidikan dan pengajaran. Atas dasar pengertian itu, permainan yang dirancang untuk member informasi atau menanamkan sikap tertentu, misalnya untuk memupuk semangat kebersamaan dan kegotongroyongan, termasuk dalam kategori permainan edukatif, karena permainan itu memberikan pengalaman belajar kognitif dan afektif. Dengan demikian, tidak menjadi soal apakah permainan itu merupaka permainan asli yang khusus dirancang untuk pendidikan ataukan permainan lama yang diberi nuansa atau dimanfaatkan untuk pendidikan.

Dapat disimpulkan bahwa alat permainan edukatif adalah segala sesuatu yang dapat dipergunakan sebagai sarana atau peralatan untuk bermain yang mengandung nilai pendidikan dan dapat merangsang otak pengembangan seluruh aspek kemampuan.

b. Manfaat Alat Permainan

Manfaat dan Ciri-ciri alat permainan edukatif menurut Suryadi yang dikutip dari jurnal publikasi pendidikan tulisan
Syamsuardi ${ }^{19}$, bahwa manfaat mainan edukatif sebagai berikut:

1. Melatih kemampuan motorik. Stimulasi untuk motorik halus diperoleh saat menjumput mainan, meraba, memegang dengan kelima jarinya, dan sebagainya, sedangkan rangsangan motorik kasar didapat anak saat menggerakkan mainannya, melempar, mengangkat dan sebagainya

2. Melatih konsentrasi. Permainan edukatif dirangsang untuk menggali kemampuan anak, termasuk kemampuannya dalam berkonsentrasi. Saat menyusun puzzel katakanlah anak dituntut untuk fokus pada gambar atau bentuk yang ada di depannya, ia tidak berlari-larian atau melakukan aktifitas fisik lain sehingga konsentrasinya bisa lebih tergali. Tanpa konsentrasi, bisa saja hasilnya tidak memuaskan.

3. Mengembangkan konsep sebab akibat. Contohnya dengan memasukkan benda kecil ke dalam benda yang besar, anak akan memahami bahwa benda yang lebih kecil bisa dimuat ke dalam benda yang lebih besar. Sedangkan benda yang lebih besar tidak bisa masuk ke dalam benda yang lebih kecil. Ini adalah pemahaman konsep sebab akibat yang sangat dasar.

${ }^{19}$ Syamsuardi, Jurnal Publikasi Pendidikan, Volume II No. 1 Februari-Mei 2012 


\begin{tabular}{|c|c|c|}
\hline$\Leftrightarrow$ & $\begin{array}{l}\text { A1 Fitrah } \\
\text { Journal Of Early Childhood Islamic Education } \\
\text { ISSN : 2599-2287 E-ISSN : 2622-335X } \\
\text { Vol.2 No.1 Juli } 2018\end{array}$ & $\begin{array}{r}\text { Sumber Belajar dan Alat Permainan } \\
\text { Untuk PAUD } \\
\text { Nurlaili }\end{array}$ \\
\hline
\end{tabular}

4. Melatih bahasa dan wawasan. Permainan edukatif sangat baik bila diikuti dengan penuturan cerita. Hal ini akan memberikan manfaat tambahan buat anak, yakni meningkatkan kemampuan bahasa juga keluasan wawasan.

5. Mengenalkan warna dan bentuk. Dari mainan edukatif, anak dapat mengenal ragam/variasi bentuk dan warna. Ada benda berbentuk kotak, segi empat, bulat, dengan berbagai warna, biru, merah, hijau dan lainnya.

c. Pentingnya Alat Permainan Edukatif

Dalam menentukan permainan edukatif, orang tua atau pendidik harus pintar dalam memilih permainan, karena tidak semua yang harganya mahal dan modern itu bersifat mendidik, bisa jadi itu hanya menanamkan sifat konsumtif pada anak. Selayaknya orang tua dan pendidik dapat memilih dan menyesuaikan media-media dan sumber belajar yang dapat mendukung perkembangan kepribadian anak, yang menyangkut fisik, intelektual, social, moral dan emosional anak.

Pemainan Edukatif penting bagi anak, disebabkan karena :

1. Permainan edukatif dapat membantu anak dalam mengembangkan dirinya.
2. Permainan edukatif mampu meningkatkan kemampuan berkomunikasi anak.

3. Permainan edukatif mampu membantu anak dalam merapikan hal baru atau member inovasi pada suatu permainan.

4. Permainan edukatif mampu meningkatkan cara berfikir pada anak.

5. Permainan edukatif mampu meningkatkan perasaan anak

6. Permainan edukatif mampu meningkatkan rasa percaya diri pada anak

7. Permainan edukatif mampu merangsang imajinasi pada anak

8. Permainan edukatif dapat melatih kemampuan bahasa pada anak

9. Permainan edukatif dapat membentuk moralitas anak

10. Permainan Edukatif dapat mengembangkan sosialisasi pada anak. $^{20}$

Contoh alat permainan edukatif bagi anak usia dini diantaranya adalah fuzzle, Building Block, menyesuaikan bilangan, jepit baju angka bintang dan lain lain. Adapun dampak permainan edukatif bagi anak adalah mampu melatih konsentrasi

https://mayadikiria.wordpress.com/2011/05/22/perm ainan-edukatif-sebagai-media-belajar-anak-usiadini/di unduh pada tanggal 11 November 2017 


\begin{tabular}{|l|l|r|}
\hline \begin{tabular}{|l|l|}
\hline \\
$y$
\end{tabular} & Al Fitrah & Sumber Belajar dan Alat Permainan \\
Journal Of Early Childhood Islamic Education & Untuk PAUD \\
ISSN : 2599-2287 E-ISSN : 2622-335X & Nurlaili \\
& Vol.2 No.1 Juli 2018 & \\
\hline
\end{tabular}

pada anak, mengajar dengan lebih cepat dengan waktu relative singkat, menambah daya pengertian dan ingatan, membuat proses belajar menyenangkan, membangkitkan emosi anak serta meningkatkan rasa sosialisasi anak dan meningkatkan kemampuan berkomunikasi pada anak.

\section{Penutup}

Pendidikan anak usia dini adalah usaha yang dilakukan oleh orang dewasa kepada anak usia 0-8 tahun dengan tujuan untuk mengembangkan potensi yang ada dalam diri anak sesuai dengan pertumbuhan dan perkembangan fisik dan rohaninya. Dalam pengembangan potensi yang ada pada anak usia dini, orang tua atau pendidik harus menggunakan sumber belajar dan alat permainan edukatif yang sesuai dengan pertumbuhan dan perkembangan anak.

\section{Daftar Pustaka}

Badru Zaman, dkk. 2007Media dan Sumber Belajar TK. Jakarta: Universitas Terbuka,

Endang Komara. 2014. Belajar dan Pembelajaran Interaktif, Bandung : Refika Aditama,

Harun Rasyid, dkk. 2009Asesmen Perkembangan Anak Usia Dini, Yogyakarta : Multi Pressindo.

Hibana S. Rahman, 2005.Konsep Dasar Pendidikan Anak Usia Dini, Yogyakarta : PGTKI Press. http://sumberbelajaraudtrisnaatika.blogspot. co.id// diunduh pada tanggal 7 November 2017

http://ariedanarmy.blogspot.co.id/2012/01/f ungsimanfaat-sumber-belajar.html, diunduh pada tanggal 10 November 2017

http://fitrianovitasari6.blogspot.co.id/2014/ $12 /$ pengertian-fungsi-jenis-jenisdan.html, diunduh pada tanggal 10 November 2017

http://vhi-

an.blogspot.co.id/2012/07/sumberbelajar-dan-media-pembelajaran.html, diunduh pada tanggal 11 November 2017

https://paudanakbermainbelajar.blogspot.co.id/20 14/04/sumber-sumber-belajar-untukanak-paud.html, diunduh pada tanggal 11 November 2017

http://www.asikbelajar.com/2015/08/bebera pa-pengertian-alat-permainan.html, diunduh pada tanggal 11 November 2017.

https://mayadikiria.wordpress.com/2011/05/ 22/permainan-edukatif-sebagaimedia-belajar-anak-usia-dini// di unduh pada tanggal 11 November 2017

Slamet Suyanto. 2005. Konsep Dasar Pendidikan Anak Usia Dini, Jakarta : Depdiknas.

Sri Winarni, Lingkungan sebagai Sumber B elajar, 2012, diunduh di http://diarywiens.blogspot.co.id/2012/ 09/lingkungan-sebagai-sumberbelajar 11.html, pada tanggal 10 November 2017 


\begin{tabular}{|l|l|r|}
\hline Al Fitrah & Sumber Belajar dan Alat Permainan \\
\hline Untuk PAUD \\
Journal Of Early Childhood Islamic Education & Nurlaili \\
\hline ISSN $:$ 2599-2287 E-ISSN : 2622-335X & \\
Vol.2 No.1 Juli 2018 & \\
\hline
\end{tabular}

Suryadi. 2007Cara Efektif Memahami Perilaku Anak Usia Dini. Jakarta: EDSA Mahkota Tedjasaputra,

Syamsuardi.2012. Jurnal Publikasi Pendidikan, Volume II No. 1

Syamsudin Makmun.2007.Psikologi Kependidikan: Perangkat Sistem Pengajaran Modul, Bandung : Rosdakarya

Undang-Undang RI Nomor 20 Tahun 2003 tentang Sistem Pendidikan Nasional 